\title{
MOST RECENT FINDINGS IN EARNINGS MANAGEMENT AREA: INTERESTING INSIGHTS FROM TRADITIONALLY TOP 5 LEADING ACCOUNTING JOURNALS
}

\author{
Dan Dacian Cuzdriorean ${ }^{1}$
}

\begin{abstract}
A meta-analysis was conducted over the last 5 years comprising traditionally top 5 leading accounting research. The paper overviews emerging research and identify both framework papers that attracted significant attention and leading scholars in the field. The earnings management area exhibits considerable momentum, found largely driven by North American scholars focused research groups. The main goal of the paper was to offer a thoroughly understanding of what literature has achieved so far and to identify further research trends that scholars can use. In this respect present study can guide researchers, but also given the economic implications of the earnings management activities, our audience can comprise as well practitioners, accounting regulators or managers. Conclusions are developed based on the sample assessed.
\end{abstract}

Keywords: Earnings management, accrual-based earnings management, real earnings management, research methods

JEL Codes: M40, M41, G34, M42

\section{Introduction}

Previous accounting scandals conducted to the confidence crisis faced in the aftermath of the financial crisis. As business environment becomes more global and international, the desire of companies to disclose strong financial figures becomes more stringent. Facing an increasing competitive economic environment, both companies and managers today do not lack the incentives to create the perfect image for the users of accounting information.

This paper regards earnings management area of research from an international point of view. In this respect an empirical analysis of the profile of contemporary published earnings management research was conducted using as sample, papers published in traditionally top 5 leading accounting journals.

The subject can be considered both timely and relevant for at least three reasons. First, earnings management activities have the potential to influence significantly both the company image and the economic outputs. By assessing this area important insights can drive the reader into a clearer view regarding both the incentives and techniques used. Second, in the aftermath of the financial crisis important shortcomings related to ethics, corporate governance or financial reporting stability are considered hot subjects. Earnings management is an item that can be easily comprised into above areas, when is not a hot subject individually considered. Third, based on the sample analysed, the most relevant and up to date research is assessed. From this demarche fruitful research paths can be identified for the benefit of a large category of scholars interested in this topic and not only. Through this paper, bridgeheads of published research can be established addressing subjects of emerging importance to a large category of audience.

The main objective of this paper is to identify the most recent research conducted in the literature with the purpose to serve as a useful instrument for the readers and to guide them to a

${ }^{1}$ Babeş-Bolyai University, Cluj-Napoca, Romania, e-mail: dan.cuzdriorean@econ.ubbcluj.ro 
deeper understanding of the topic. Also the scope of this study is to augment the literature. This study covers a period of 5 years (2008-2013).

Given the length of the earnings management area, I have narrowed the scope of this state of the art into two ways. First, this particular review will focus only on traditionally top 5 leading accounting journals. Second, this state of the art paper will assess the most recent research (e.g. the last 5 years).

This research is guided by summarizing the main findings developed by traditionally top 5 leading accounting journals scholars. Since meta-analysis was used, descriptive information about earnings management research in the traditionally top 5 leading accounting journals is also approached.

The findings of this particular paper outlines the relevance of top leading journals in creating a strong and continuing tradition by providing important insights that has the potential to highlight areas for further development of research and policy. This paper also discusses the latest trend in research from the earnings management arena, while describing the scholarship field.

Four sections are comprised in the present paper. Section two offers a brief description over the methodology used. Section three comprises the Meta-analysis segment, while section four comprises the segment of discussions. Last, conclusions segment outline the main springs of research for future earnings management research, while the limitations of the research conducted are explained.

\section{Research question}

In order to achieve the goal of this research, a meta-analysis is conducted. This particular research method was chosen in order to evaluate, identify and address future research springs of research. As stated earlier this research covers the last 5 years period.

In order to clarify future agendas of research two research questions were developed as follows:

Q1: What is the scholarship field of earnings management research based on the traditionally top 5 leading accounting journals?

Q2: What is the future of earnings management research based on the traditionally top 5 leading accounting journals?

\section{Research method}

This segment explains the method used by the author in order to select and assess the papers from the sample. The method for achieving this goal was the one used in previous studies (e.g. Guthrie et al., 2012). Five stages were comprised in the research method.

In the first stage the core objectives of the study were formulated, followed by the second stage when the selection of the articles was comprised.

Following the view of Chan et al. (2009) the sample of journals comprised are the traditionally top 5 leading accounting journals. In this respect a number of five accounting journals were selected as following: The Accounting Review, The Accounting and Economics, The Contemporary Accounting Research, Journal of Accounting Research and Accounting, Organizations and Society. The choice of the above leading accounting journals is made taking into account that this review considered only articles published in the mainstream accounting journals, rather than generalist research journals. The third stage included the selection of articles. This particular stage included specific keywords using in order to identify papers from earnings management area. Typical examples of keywords used were: earnings management, accruals, abnormal accruals, real earnings management. A total of 168 full version papers were selected. All papers selected are PDF versions and were downloaded and stored as Endnote database with the references. In the next stage an examination of all papers was conducted in order to identify the core focus. It was in this particular stage when some papers were excluded based on their marginal focus on earnings management activities. A number of 75 full papers remained. Workings papers 
and conferences proceedings papers were not included. In the last stage was included a descriptive statistics, presented in the next segment of the paper.

\section{Meta - analysis}

The purpose of this segment is to provide the reader with a meta-analysis of the earnings management area of research. Also, in order to be able to the above research questions, this segment comprises the main answers that can lead to an assessment of the scholarship field of earnings management.

Table no. 1 considers the spread of traditionally top 5 leading accounting journals. This is considered before the classification framework and the discussion segment. For each journal, the number of published papers from earnings management area is summarized.

\section{Earnings management publication frequency by journal}

Table no. 1

Traditionally top 5 leading accounting journals/frequency of paper per journal (2008-2013)

\begin{tabular}{|l|c|c|c|}
\hline \multicolumn{1}{|c|}{ Journal name } & Journal code & $\begin{array}{c}\text { Earnings } \\
\text { management papers }\end{array}$ & $\begin{array}{c}\text { Percentage } \\
(\boldsymbol{\%})\end{array}$ \\
\hline Accounting, Organizations and Society & AOS & 5 & 6,66 \\
\hline Contemporary Accounting Research & CAR & 24 & 32,00 \\
\hline Journal of Accounting and Economics & JAE & 22 & 29,33 \\
\hline Journal of Accounting Research & JAR & 3 & 4,00 \\
\hline The Accounting Review & TAR & 21 & 28,00 \\
\hline Grand total & 5 & 75 & 100,00 \\
\hline
\end{tabular}

Source: Author's projection

From the leading journals examined, Contemporary Accounting Research journal was the one that published the most significant number of papers from earnings management area (32\%) while the Journal of Accounting and Economics is the second one that attracted the most attention with $29 \%$ from the total papers under review. The Accounting Review journal published $28 \%$ of the papers analysed. The smallest number of papers from earnings management area was published by Accounting, Organizations and Society (e.g. 5\%) followed by the Journal of Accounting Research that published only 3 papers in the last 5 years that had a core focus on earnings management activities.

\section{Earnings management findings (2008-2013)}

Annex no. 1 summarizes the main findings from each paper examined from the sample. For the purposes of summarizing the information, similar research purposes and findings were comprised in the same segment.

Earnings management papers from top 5 leading accounting journals for the year 2008 seems to be influenced by two items of high interest: occurrence and magnitude. In this respect, the large majority of papers published in 2008, are interested to assess the magnitude of abnormal accruals, to indentify situations that has the potential to lead to earnings management occurrence (e.g. deferred taxes, specific investments, meet or beat analysts targets, initial public offerings) and to test the power of earnings management detection models. Also it was of interest to identify items that can lead to decrease of earnings management (e.g. staggered boards, industry or firm-level proxies, conformity increasing).

Year 2009 published research on earnings management in top 5 leading accounting journals has mainly concentrated in ways of reducing earnings management activities and to document what factors influence the occurrence of it. The main findings documented that environmental 
uncertainty, CEO equity increase, weak strong governance, low quality of internal audit, auditor tenure, intra-year earnings patterns are factors associated with the occurrence of earnings management.

In the case of year 2010 published earnings management research in the approached journals detection methods are assessed primarily. In this respect items like: conservatism, financial transparency, revenues models for detection manipulative activities, SEO activities are associated with an increase of the magnitude of abnormal accruals. Also is documented that earnings management activities are not employed only opportunistically but also for signaling purposes. In the same time factors influencing its appearance are assesses, like: fair value, R\&D expenses, product market competition.

The earnings managements published research in year 2011 is continuing the previous years 'topics of interest and asses factors that influence the appearance of earnings management (e.g. recognition; warranty estimations; low corporate governance; lack of local monitoring institutions). Evidences on earnings management activities are documented in: non-core operational expenses in non-profit firms, over valuated firms, CFOs decisions under CEOs pressure, warranty, expense misclassification.

Year 2012 published research comprise research mainly approaching ways to improve the detection models used previously in the literature (e.g. intrusion of reversals, intent assessment, forward looking provisioning assessment). Factors like: investor protection, audit quality, local ownership are among the ones documented for decreasing the magnitude of manipulation.

The last year introduced credit ratings assessment via earnings management occurrence, staged impression management, continuing non-GAAP earnings assessment, misreporting empirical assessment magnitude, forecast accuracy. The last year experience seems not to continue with traditional detection models but to focus more on the quality of earnings, forecast and quality of financial reporting.

\section{The methodological mix}

Table no. 2 presents the methodological mix. The research methodologies employed in papers published in the traditionally top 5 leading journals were analyzed for a period of 5 years covered by 2008-2013. The categories comprised were: interview; descriptive survey; archival/historical analysis/discussions; literature review; mathematical and statistical analysis; experiment. The categories from Table no. 2 are self explanatory. Similar like in previous studies that used the meta-analysis as research method (e.g. Parker, 2011), when a paper included more than one research method it was categorized according to the main research method used for primary data analysis.

Table no. 2

Methodological mix

\begin{tabular}{|l|c|c|}
\hline $\begin{array}{c}\text { Research methods employed in } \\
\text { papers reviewed }\end{array}$ & $\begin{array}{c}\text { No. of studies including } \\
\text { the methodology }\end{array}$ & $\begin{array}{c}\text { Percentage } \\
(\mathbf{\%})\end{array}$ \\
\hline Theoretical & 2 & 2,66 \\
\hline Descriptive survey & 1 & 1,33 \\
\hline Descriptive case study & 0 & 0,00 \\
\hline $\begin{array}{l}\text { Archival/historical } \\
\text { analysis/discussions }\end{array}$ & 1 & 1,33 \\
\hline Literature review & 3 & 4,00 \\
\hline $\begin{array}{l}\text { Mathematical analysis/statistical } \\
\text { analysis }\end{array}$ & 63 & 84,00 \\
\hline Experiment & 5 & 6,66 \\
\hline Grand total & 75 & 100,00 \\
\hline
\end{tabular}

Source: Author's projection 
From this particular research the main conclusion in regard of the research methods used predominantly in traditionally top 5 leading accounting journals, is that there is an underused approach through accounting research. Over the whole sample and period under analysis the dominant research method was the mathematical and statistical method (e.g. Baker et al., 2009; Bowen et al., 2008; Caramanis and Lennox, 2008; Ball and Shivakumar, 2008; Chen et al. 2008; Cohen et al., 2008; Cook et al., 2008; Daniel et al., 2008; Davis et al., 2008; Gong et al., 2008; Hanlon et al., 2008; Jones et al., 2008; Koh et al., 2008; McAnnaly et al, 2008; McNichols and Stubben, 2008; Raman and Shahrur, 2008; Zhao and Chen, 2008; Badertscher et al., 2009; Das et al., 2009; Feng et al., 2009; Ghosh and Olsen, 2009; Prawitt et al., 2009; Bagnoli and Watts, 2010; Barua et al., 2010; Cohen and Zarowin, 2010; Dechow et al., 2010; Gunny, 2010; Jackson and Liu, 2010; Stubben, 2010; Ayers et al., 2011; Baber et al., 2011; Badertscher, 2011; Chen et al., 2011; Cohen et al., 2011; Choudhary, 2011; Das et al., 2011; Dechow et al., 2011; Eldenburg et al., 2011; Feng et al., 2011; Haw et al., 2011; McInnis and Collins, 2011; Ahmed et al., 2012; Badertscher et al., 2012; Beneish et al, 2012; Burnett et al., 2012; Boone et al., 2012; Bushman and Williams, 2012; Chhaochharia et al., 2012; Dechow et al., 2012; Gopalan and Jayaraman, 2012; Jansen et al., 2012; Jung et al., 2012; Klassen and Laplante, 2012; Schrand and Zechman, 2012; Zang, 2012; Alissa et al., 2013; Donelson et al., 2013; Doyle et al., 2013; Gao. 2013; Horton et al., 2013; Gerakos and Kovrijnykh, 2013; Wongsunwal, 2013), followed by experiment research method (Nan, 2008; Peecher and Piercey, 2008; Seybert, 2010; Chen et al., 2012; Murphy, 2012).

Literature review research method comprised a number of 3 papers (Armstrong et al., 2010; Graham et al., 2012; Solomon et al., 2013) while theoretical approaches comprised a number of 2 papers (e.g. Beyer, 2009; Laux and Laux, 2009). Only one paper was comprised in the descriptive survey segment (e.g. Johnson et al., 2012) and archival/historical analysis/discussions (e.g. Barth and Taylor, 2010). None of the studies approached as core research method the descriptive case study.

From observing the methodological profile of earnings management research published in traditionally top 5 leading accounting journals, an important conclusion can be developed. Of part of the strategy of greater earnings management engagement, more field interviews and case studies research methodologies are arguably considerable. The scholarship field of earnings management is very little qualitative or joint method since the empirical research is the dominant one.

\section{Authorship and location}

By analysing the authorship and location provides the basis for the meta-analysis and discussion of the earnings management field over the period covered. In reviewing the profile of the earnings management field, with the purpose of identifying the authors most frequently appearing the 2008-2013 sample is examined. Also the location examination is covered.

Table no. 3

Authorship and location in traditionally top 5 leading accounting journals (2008-2013)

\begin{tabular}{|l|c|}
\hline \multicolumn{1}{|c|}{ Country } & Number of authors \\
\hline United States of America & 165 \\
\hline China & 8 \\
\hline United Kingdom & 6 \\
\hline Canada & 5 \\
\hline Australia & 2 \\
\hline Spain & 2 \\
\hline Germany & 2 \\
\hline Greece & 2 \\
\hline Singapore & 3 \\
\hline \multicolumn{2}{|c|}{} \\
\hline
\end{tabular}




\begin{tabular}{|l|c|}
\hline France & 1 \\
\hline Number of countries & $\mathbf{1 0}$ \\
\hline Number of authors & $\mathbf{1 9 6}$ \\
\hline
\end{tabular}

Source: Author's projection

Looking for the most prolific scholars publishing in traditionally top 5 leading accounting journals approaching the area of earnings management, it can be concluded that North America scholars only are among them. In this respect the one that publish more frequent in the periods under review were (in alphabetical order): Daniel Cohen (USA); Patricia Dechow (USA); Katherine Gunny (USA) and John McInnis (USA). The North America is the most represented in the sample with the highest number of scholars publishing in traditionally top 5 leading accounting journals followed by an emerging economy (e.g. China -8 scholars), United Kingdom (6 scholars) and Canada (5 scholars). A similar number of authors can be identified from countries as: Australia (2 scholars), Spain, Germany and Greece. France is represented in the period under review by one single scholar. A total number of 196 authors published in the last five years in traditionally top 5 leading accounting journals topics from earnings management area, from 10 countries as it can be seen in Table no. 3.

Above categories are the most frequent contributors during the last five years period even if earnings management area of research is approached by many more authors from many regions of the world. Continental Europe or Australia is not equally represented compared with the main locations approached above. Also, other emerging economies are less represented (except the case of China).

\section{Discussions}

This particular segment outlines the meta-analysis findings and opens the door for discussion of the main findings, from a more qualitative perspective with the goal of answering to the research questions above. To be able to find an answer to those research questions, it was necessary to identify the broad research paths addressed.

A first idea that can be developed based on the sample analyzed is related to the international focus of the earnings management field under analyze. Most of the papers examined approaches are using country comparative approaches, international business or universal research paths that can be replicated elsewhere. Only a small segment of studies examined a single country.

Based on the number of articles published in the traditionally top 5 leading accounting journals examining earnings management field, can be concluded that this field of research is not neglected in top 5 leading accounting journals. This area, by having a high profile internationally is predominantly assessed on the agendas of both media coverage worldwide and political debate. Based on its impact on economic environment, is well represented also in the traditionally top 5 leading accounting journals but not only.

Scholars contributing to earnings management research published in traditionally top 5 leading accounting journals are ignoring qualitative research, empirical research being preferred. One explanation can be the nature of this area of research. Theoretical perspectives methodologies are very less represented in those "high ranking" journals.

The analysis of earnings management area included both countries and individuals assessing as it was stated earlier. In the last 5 years preferred topics are related to: improvement of the detection techniques, identify factors that can limit or increase earnings management, the impact of audit and corporate governance, financial transparency or conservatism on earnings management.

By addressing future area of research, numerous scholars' conceits are taken into account. In looking for those suggestions, several mentioned the need for more research improving the power of the models use for detection and assessing the quality of financial reporting. There are also a 
number of items that didn't appeared in the last 5 years period and are worthy of more concentrated efforts of research like the impact of ethics or disclosure on earnings management.

\section{Conclusions, limitations and future agenda}

This paper do not meant to be a definitive framework for earnings management research area. There are still a large number of papers approaching this area of research but very few are published in traditionally top 5 leading accounting journals. The scope of this paper was to assist the reader in an organizing way to get access to the most recent and relevant field of research of earnings management area. In this respect, this study can be a useful instrument in identifying future areas of research.

The 75 full papers analyzed investigated new ideas and extended prior research conducted. Over the last 5 years, traditionally top 5 leading accounting journals devoted to earnings management area substantially attention. If we take into account the fact that a significant number of papers are published in accounting, management and generalist journals, this area is substantially represented worldwide, being considered a hot area of study. In the light of previous accounting scandals, IFRS implementation or financial crisis context, it becomes even more approached.

Based on the meta-analysis conducted the answers to the research questions defined above can be drawn. "What is the scholarship field of earnings management research based on the traditionally top 5 leading accounting journals?" was the first research question. By reviewing the literature approached above, the scholarship field is identified, as a specialist field of research and presented in the meta-analysis segment. Next, it can be advocated paths to answering the second research question developed: "What is the future of earnings management research based on the traditionally top 5 leading accounting journals?" Based on the significant number of papers published and items of research addressed on the last 5 years, can be accepted that there is a greater potential for earnings management area to be even more approached in the future in traditionally top 5 leading accounting journals and not only.

The range of research methods applied in this field is not balanced across a full suite of methods in the more recent years. In this respect mathematical and statistical analysis covers the significant majority of papers published followed by experiment. Research methods like descriptive survey are underused. In this respect untried research methods can broad the range of research methods used. The dominant publishers were the Contemporary Accounting Research, that published 32\% of the papers under review and Journal of Accounting and Economics that published $29 \%$ of the papers from the sample used.

The findings and observations of leading research groups concentrate on improving the detection models of earnings management, its magnitude and impact, together with finding the factors that can lead to an increase of its magnitude. Similar results can be found in previous studies (Stolowy and Breton, 2004; Dechow et al., 2010).

Although this area increased substantially, is still room for more research conducted in order to approach areas where still much controversy exists, like: income smoothing assessment, the impact of financial crisis over manipulation behaviour, personal traits impact over earnings management activities, etc. Those future research agendas can open up new fields of enquiry, addressing either neglected areas of research either consolidating previous areas of earnings management research. Also, future research should also consider exploring previous findings using qualitative research including interviews with managers, investors or other users of accounting information.

The conclusions of this paper have also several practical implications. First, more financial transparency and disclosure is needed in the view of users of accounting information in order to assess the quality of financial reporting. Second, accounting standard regulators should bear in mind the incidence of earnings management activities in sectors that prove to be vulnerable to manipulation, according to the empirical studies conducted in the literature so far. 
As it was stated earlier much controversy still exists in the area of earnings management, so many challenges remain to continue answering the emerging questions.

Earnings management area is clearly established as a specialist area, comprising a significant stream of research in the accounting literature, still bearing important hallmarks for continuous investigation, both theoretical and empirical.

\section{References}

1. Ahmed A.S., Neel M., Wang D., 2012. Does Mandatory Adoption of IFRS Improve Accounting Quality? Preliminary Evidence, Contemporary Accounting Research, DOI: $10.1111 / \mathrm{j} .1911-3846.2012 .01193 . x$

2. Alissa W., Bonsall IV S.B., Koharki K., Penn Jr. M.W., 2013. Firms' use of accounting discretion to influence their credit ratings, Journal of Accounting and Economics, volume 55, pp. 129-147

3. Armstrong C.S., Guay W.R., Weber J.P., 2010. The role of information and financial reporting in corporate governance and debt contracting, Journal of Accounting and Economics, volume 50, pp. 179-234

4. Ayers B.C., Remalingegowda S., Yeung P.E., 2011. Hometown advantage: The effects of monitoring institution location on financial reporting discretion, Journal of Accounting and Economics, volume 52, pp. 41-61

5. Baber W.R., Kang S-H., Li Y., 2011. Modeling Discretionary Accrual Reversal and the Balance Sheet as an Earnings Management Constraint, The Accounting Review, volume 86 , number 4, pp. 1189-1212

6. Badertscher B., 2011. Overvaluation and the Choice of Alternative Earnings Management Mechanisms, The Accounting Review, volume 86, number 5, pp. 1491-1518

7. Badertscher B.A., Collins D.W., Lys T.Z., 2012. Discretionary accounting choices and the predictive ability of accruals with respect to future cash flows, Journal of Accounting and Economics, volume 53, pp. 330-352

8. Badertscher,B., Phillips J., Pincus M., Rego S., 2009. Earnings Management Strategies and the Trade-off Between Tax Benefits and Detection Risk: To Conform or not to Conform?, The Accounting Review, volume 84, number 1, pp. 63-97

9. Bagnoli M., Watts S.G., 2010. Oligopoly, Disclosure, and Earnings Management, The Accounting Review, volume 85, number 4, pp. 1191-1214

10. Baker T.A., Collins D.L., Reitenga A.R., 2009. Incentives and Opportunities to Manage Earnings around Option Grants, Contemporary Accounting Research, volume 26, number 3, pp. 649-672

11. Ball R., Shivakumar L., 2008. Earnings quality at initial public offerings, Journal of Accounting and Economics, volume 45, pp. 324-349

12. Barua A., Lin S., Sbaraglia A., 2010. Earnings Management Using Discontinued Operations, The Accounting Review, volume 85, number 5, pp. 1485-1509

13. Barth M., Taylor D., 2010. In defense of fair value: Weighing the evidence on earnings management and asset securitizations, Journal of Accounting and Economics, volume 49, pp. 26-33

14. Beneish M.D., Press E., Vargus M.E., 2012. Insider Trading and Earnings Management in Distressed Firms, Contemporary Accounting Research, volume 29, number 1, pp. 191-220

15. Beyer A., 2009. Capital Market Prices, Management Forecasts, and Earnings Management, The Accounting Review, volume 84, number 6, pp. 1713-1747

16. Boone J.F., Khurana I.K., Raman K.K., 2012. Audit Market Concentration and Auditor Tolerance for Earnings Management, Contemporary Accounting Research, volume 29, number 4, pp. 1171-1203 
17. Bowen R.M., Rajgopal S., Venkatachalam M., 2008. Accounting Discretion, Corporate Governance, and Firm Performance, Contemporary Accounting Research, volume 25, number 2, pp. 351-405

18. Burnett B., Cripe B., Martin G., McAllister B., 2012. Audit Quality and the Trade-Off between Accretive Stock Repurchases and Accrual-Based Earnings Management, The Accounting Review, volume 87, number 6, pp. 1861-1884

19. Bushman R.M., Williams C.D., 2012. Accounting discretion, loan loss provisioning, and discipline of Banks' risk-taking, Journal of Accounting and Economics, volume 54, pp. 1-18

20. Caramanis C., Lennox C., 2008. Audit effort and earnings management, Journal of Accounting and Economics, volume 45, pp. 116-138

21. Chan K., Liano K., 2009. A Threshold Citation Analysis of Influential Articles, Journals, Institutions and researchers in Accounting, Journal of Accounting and Finance, volume 49, issue 1, pp. 59-74

22. Chen Q., Kelly K, Salterio S.E., 2012. Do changes in audit actions and attitudes consistent with increased auditor skepticism deter aggressive earnings management? An experimental investigation, Accounting, Organizations and Society, volume 37, pp. 95-115

23. Chen H. Chen J.Z., Lobo G.J. Wang Y., 2011. Effects of Audit Quality on Earnings Management and Cost of Equity Capital: Evidence from China, Contemporary Accounting Research, volume 28, number 3, pp. 892-925

24. Chen C-Y., Lin C-J., Lin Y-C., 2008. Audit Partner Tenure, Audit Firm Tenure, and Discretionary Accruals: Does Long Auditor Tenure Impair Earnings Quality?, Contemporary Accounting Research, volume 25, number 2, pp. 415-445

25. Chhaochharia V., Kumar A., Niessen-Ruenzi A., 2012. Local investors and corporate governance, Journal of Accounting and Economics, volume 54, pp. 42-67

26. Choudhary P., 2011. Evidence on differences between recognition and disclosure: A comparison of inputs to estimate fair values of employee stock options, Journal of Accounting and Economics, volume 51, pp. 77-94

27. Cohen D., Darrough M., Huang R., Zach T., 2011. Warranty Reserve: Contingent Liability, Information Signal, or Earnings Management Tool?, The Accounting Review, volume 86, number 2, pp. 569-604

28. Cohen D.A., Zarowin P., 2010. Accrual-based and real earnings management activities around seasoned equity offerings, Journal of Accounting and Economics, volume 50, pp. 219

29. Cohen D., Dey A., Lys T., 2008. Real and Accrual-Based Earnings Management in the Preand Post-Sarbanes-Oxley Periods, The Accounting Review, volume 83, number 3, pp. 757 787

30. Cook K.A., Huston G.R., Omer T.C., 2008. Earnings Management through Effective Tax Rates: The Effects of Tax-Planning Investment and the Sarbanes-Oxley Act of 2002, Contemporary Accounting Research, volume 25, number 2, pp. 447-471

31. Daniel N.D., Denis D.J., Naveen L., 2008. Do firms manage earnings to meet dividend thresholds?, Journal of Accounting and Economics, volume 45, pp. 2-26

32. Das S., Kim K., Patro S., 2011. An Analysis of Managerial Use and Market Consequences of Earnings Management and Expectation Management, The Accounting Review, volume 86, number 6, pp. 1935-1967

33. Das S., Shroff P.K., Zhang H., 2009. Quarterly Earnings Patterns and Earnings Management, Contemporary Accounting Research, volume 26, number 3, pp. 797-831

34. Davis L.R., Soo B.S., Trompeter G.M., 2009. Auditor Tenure and the Ability to Meet or Beat Earnings Forecasts, Contemporary Accounting Research, volume 26, number 2, pp. 517-548

35. Dechow P., Hutton A., Kim J.H., Sloan R.G., 2012. Detecting Earnings Management: A 
New Approach, Journal of Accounting Research, volume 50, number 2, pp. 275-334

36. Dechow P.M., Ge, W., Larson C.R., Sloan R.S., 2011. Predicting Material Accounting Misstatements, Contemporary Accounting Research, volume 28, number 1, pp. 17-82

37. Dechow P.M., Myers L.A., Shakespeare C., 2010. Fair value accounting and gains from asset securitizations: A convenient earnings management tool with compensation sidebenefits, Journal of Accounting and Economics, volume 49, pp. 2-25

38. Donelson D.C., Mcinnis J.M., Mergenthaler R.D., 2013. Discontinuities and Earnings Management: Evidence from Restatements Related to Securities Litigation, Contemporary Accounting Research, volume 30, number 1, pp. 242-268

39. Doyle J.T., Jennings J., Soliman M.T., 2013. Do Managers Define Non-GAAP Earnings to Meet or Beat Analyst Forecasts?, Journal of Accounting and Economics, volume 56, pp. 4056

40. Eldenburg L., Gunny K., Hee K., Soderstrom N., 2011. Earnings Management Using Real Activities: Evidence from Nonprofit Hospitals, The Accounting Review, volume 86, number 5, pp. 1605-1630

41. Feng M., Ge W., Luo S., Shevlin T., 2011. Why do CFOs become involved in material accounting manipulations?, Journal of Accounting and Economics, volume 51, pp. 21-36

42. Feng M., Gramlich J., Gupta S., 2009. Special Purpose Vehicles: Empirical Evidence on Determinants and Earnings Management, The Accounting Review, volume 84, number 6, pp. 1833-1876

43. Gao P., 2013. A measurement approach to conservatism and earnings management, Journal of Accounting and Economics, volume 55, pp. 251-268

44. Garcia Osma B., Guillamon-Saorin E., 2011. Corporate governance and impression management in annual results press releases, Accounting, Organization and Society, volume 36, pp. 187-206

45. Gerakos J., Kovrijnykh A., 2013. Performance Shocks and Misreporting, Journal of Accounting and Economics, volume 56, pp. 57-72

46. Ghosh D., Olsen L., 2009. Environmental uncertainty and managers' use of discretionary accruals, Accounting, Organizations and Society, volume 34, pp. 188-205

47. Gong G., Louis H., Sun A.X., 2008. Earnings management, lawsuits, and stock-for-stock acquirers' market performance, Journal of Accounting and Economics, volume 46, pp. 6277

48. Gopalan R., Jayaraman S., 2012. Private Control Benefits and Earnings Management: Evidence from Insider Controlled Firms, Journal of Accounting Research, volume 50, number 1, pp. 117-157

49. Graham J.R., Raedy J.S., Shackelford D.A., 2012. Research in accounting for income taxes, Journal of Accounting and Economics, volume 53, pp. 412-434

50. Gunny K.A., 2010. The Relation Between Earnings Management Using Real Activities Manipulation and Future Performance: Evidence from Meeting Earnings Benchmarks, Contemporary Accounting Research, volume 27, number 3, pp. 855-888

51. Guthrie J., Ricceri F., Dumay J., 2012. Reflections and projections: A decade of Intellectual Capital Accounting Research, The British Accounting Review, volume 44, pp. 68-82

52. Hanlon M., Maydew E.L., Shevlin T., 2008. An unintended consequence of book-tax conformity: A loss of earnings informativeness, Journal of Accounting and Economics, volume 46, pp. 294-311

53. Haw I.M., Ho S.S.M., Li A.Y., 2011. Corporate Governance and Earnings Management by Classification Shifting, Contemporary Accounting Research, volume 28, number 2, pp. $517-$ 553

54. Horton J., Serafeim, G., Serafeim I., 2013. Does Mandatory IFRS Adoption Improve the Information Environment?, Contemporary Accounting Research, volume 30, number 1, pp. 
388-423

55. Jackson S.B., Liu X.T., 2010. The Allowance for Uncollectible Accounts, Conservatism, and Earnings Management, Journal of Accounting Research, volume 48, number 3, pp. 565-601

56. Jansen I.P., Ramnath S., Yohn T.L., 2012. A Diagnostic for Earnings Management Using Changes in Asset Turnover and Profit Margin, Contemporary Accounting Research, volume 29, number 1, pp. 221-251

57. Johnson E.N., Fleischman G.M., Valentine S., Walker K.B., 2012. Managers' Ethical Evaluations of Earnings Management and Its Consequences, Contemporary Accounting Research, volume 29, number 3, pp. 910-927

58. Jones K.L., Krishnan G.V., Melendrez K.D., 2008. Do Models of Discretionary Accruals Detect Actual Cases of Fraudulent and Restated Earnings? An Empirical Analysis, Contemporary Accounting Research, volume 25, number 2, pp. 499-531

59. Jung B., Soderstrom N., Yang Y.S., 2012. Earnings Smoothing Activities of Firms to Manage Credit Ratings, Contemporary Accounting Research, doi:10.1111/j.19113846.2012.01170.x

60. Klassen K.J., Laplante S.K., 2012. The Effect of Foreign Reinvestment and Financial Reporting Incentives on Cross-Jurisdictional Income Shifting, Contemporary Accounting Research, volume 29, number 3, pp. 928-955

61. Koh K., Matsumoto D.A., Rajgopal S., 2008. Meeting or Beating Analyst Expectations in the Post-Scandals World: Changes in Stock Market Rewards and Managerial Actions, Contemporary Accounting Research, volume 25, number 4, pp. 1067-1098

62. Laux C., Laux V., 2009. Board Committees, CEO Compensation, and Earnings Management, The Accounting Review, volume 84, number 3, pp. 869-891

63. McAnally M., Srivastava A., Weaver C., 2008. Executive Stock Options, Missed Earnings Targets, and Earnings Management, The Accounting Review, volume 83, number 1, pp. $185-216$

64. McInnis J., Collins D.W., 2011. The effect of cash flow forecasts on accrual quality and benchmark beating, Journal of Accounting and Economics, volume 51, pp. 219-239

65. McNichols M.F., Stubben S.R., 2008. Does Earnings Management Affect Firms' Investment Decisions?, The Accounting Review, volume 83, number 6, pp. 1571-1603

66. Murphy P.L., 2012. Attitude, Machiavellianism and the rationalization of misreporting, Accounting, Organization and Society, volume 37, pp. 242-259

67. Nan L., 2008. The Agency Problems of Hedging and Earnings Management, Contemporary Accounting Research, volume 25, number 3, pp. 859-889

68. Parker L.D., 2011. Twenty-one years of social and environmental accountability research: A coming of age, Accounting Forum, volume 35, pp. 1-10

69. Prawitt D., Smith J., Wood D., 2009. Internal Audit Quality and Earnings Management, The Accounting Review, volume 84, number 4, pp. 1255-1280

70. Peecher M.E., Piercey M.D., 2008. Judging Audit Quality in Light of Adverse Outcomes: Evidence of Outcome Bias and Reverse Outcome Bias, Contemporary Accounting Research, volume 25, number 1, pp. 243-274

71. Raman K., Shahrur H., 2008. Relationship-Specific Investments and Earnings Management: Evidence on Corporate Suppliers and Customers, The Accounting Review, volume 83, number 4, pp. 1041-1081

72. Schrand C.M., Zechman S.L.C., 2012. Executive overconfidence and the slippery slope to financial misreporting, Journal of Accounting and Economics, volume 53, pp. 311-329

73. Seybert N., 2010. R\&D Capitalization and Reputation-Driven Real Earnings Management, The Accounting Review, volume 85, number 2, pp. 671-693

74. Solomon J.F., Solomon A., Joseph N.L., Norton S.D., 2013. Impression management, myth creation and fabrication in private social and environmental reporting: Insights from 
Erving Goffman, Accounting, Organization and Society, volume 38, pp. 195-213

75. Stubben S., 2010. Discretionary Revenues as a Measure of Earnings Management, The Accounting Review, volume 85, number 2, pp. 695-717

76. Wongsunwai, W., 2013. The Effect of External Monitoring on Accrual-Based and Real Earnings Management: Evidence from Venture- Backed Initial Public Offerings, Contemporary Accounting Research, volume 30, number 1, pp. 296-324

77. Zang A., 2012. Evidence on the Trade-Off between Real Activities Manipulation and Accrual-Based Earnings Management, The Accounting Review, volume 87, number 2, pp. 675-703

78. Zhao Y., Chen K., 2008. Staggered Boards and Earnings Management, The Accounting Review, volume 83, number 5, pp. 1347-1381

Findings of papers published in traditionally top 5 leading accounting

Annex no. 1

\begin{tabular}{|c|c|}
\hline $\begin{array}{l}\text { Years } \\
2008\end{array}$ & Main Findings \\
\hline \multirow[t]{29}{*}{2008} & Ball and Shivakumar, 2008 \\
\hline & Contrary to popular belief, initial public offering (IPO) firms report more conservatively. \\
\hline & Hanlon et al., 2008 \\
\hline & When increasing conformity results in earnings that are less informative. \\
\hline & Gong et al., 2008 \\
\hline & $\begin{array}{l}\text { It is important that investors not only undo the direct stock price effects on earnings management but } \\
\text { also factor the contingent legal costs associated with earnings management. }\end{array}$ \\
\hline & Daniel et al., 2008 \\
\hline & $\begin{array}{l}\text { Dividend-paying firms tend to manage earnings upward when their earnings would otherwise fall short } \\
\text { of expected dividend levels. }\end{array}$ \\
\hline & Caramanis and Lennox, 2008 \\
\hline & $\begin{array}{l}\text { When audit hours are lower: (1) abnormal accruals are more often positive than negative, (2) positive } \\
\text { abnormal accruals are larger, and ( } 3 \text { ) companies are more likely to manage earnings upwards in order to } \\
\text { meet or beat the zero earnings benchmark. }\end{array}$ \\
\hline & Nan, 2008 \\
\hline & $\begin{array}{l}\text { When the decision to hedge is contractible, hedging alleviates the agency problem by reducing both the } \\
\text { risk premium and the equilibrium amount of earnings management. }\end{array}$ \\
\hline & Bowen et al., 2008 \\
\hline & $\begin{array}{l}\text { The portion of accruals associated with poor governance quality is not negatively associated with future } \\
\text { earnings and cash flows. }\end{array}$ \\
\hline & Koh et al., 2008 \\
\hline & $\begin{array}{l}\text { The proportion of small EPS beats has fallen in the post scandals period, suggesting that managers } \\
\text { appear to have cut actions to exactly meet or just beat expectations. }\end{array}$ \\
\hline & Jones et al., 2008 \\
\hline & $\begin{array}{l}\text { Only the accrual estimation errors estimated from cross-sectional models of working capital changes on } \\
\text { past, present, and future cash flows (Dechow and Dichev 2002) and the McNichols } 2002 \text { modification of } \\
\text { Dechow and Dichev have predictive power for both fraud and non-fraudulent restatements of earnings. }\end{array}$ \\
\hline & Cook et al., 2008 \\
\hline & $\begin{array}{l}\text { Tax fees are robust to the inclusion of other common earnings management variables, including total and } \\
\text { discretionary accruals and deferred taxes. }\end{array}$ \\
\hline & Chen et al., 2008 \\
\hline & $\begin{array}{l}\text { The absolute and positive values of discretionary accruals decrease significantly with audit partner } \\
\text { tenure. }\end{array}$ \\
\hline & Peecher and Piercey, 2008 \\
\hline & $\begin{array}{l}\text { Neither identifies, nor contends that it can be identify, the optimal prior beliefs for negligence or } \\
\text { misstatement in either context. }\end{array}$ \\
\hline & McNichols and Stubben, 2008 \\
\hline & Earnings management practices can influence internal decisions. \\
\hline & Zhao and Chen, 2008 \\
\hline & Staggered boards are associated with lower unexpected accruals. \\
\hline & $\begin{array}{l}\text { Raman and Shahrur, } 2008 \\
\text { The magnitude of discretionary accruals is as }\end{array}$ \\
\hline
\end{tabular}




\begin{tabular}{|c|c|}
\hline & for specific investments. \\
\hline & $\begin{array}{l}\text { McAnally et al., } 2008 \\
\text { Document incentives for firms to miss earnings target. Managers time their options after missing } \\
\text { earnings targets. }\end{array}$ \\
\hline & $\begin{array}{l}\text { Cohen et al., } 2008 \\
\text { Increase in earnings management in the period preceding the passage of SOX. While the level of } \\
\text { accrual-based EM declined, the real EM activities increased significantly after the passage of SOX. }\end{array}$ \\
\hline \multirow[t]{9}{*}{2009} & $\begin{array}{l}\text { Ghosh and Olsen, } 2009 \\
\text { The magnitude of discretionary accruals is greater when environmental uncertainty is high. }\end{array}$ \\
\hline & $\begin{array}{l}\text { Laux and Laux, } 2009 \\
\text { CEO equity increases do not necessarily increase the magnitude of EM. }\end{array}$ \\
\hline & $\begin{array}{l}\text { Feng et al., } 2009 \\
\text { Strong corporate governance limits the influence of special purpose vehicles. }\end{array}$ \\
\hline & $\begin{array}{l}\text { Beyer , } 2009 \\
\text { Managers manipulate earnings to reduce the forecast error. }\end{array}$ \\
\hline & $\begin{array}{l}\text { Prawitt et al., } 2009 \\
\text { Internal audit quality is associated with a moderate level of EM. }\end{array}$ \\
\hline & $\begin{array}{l}\text { Badertscher et al., } 2009 \\
\text { Earnings management activities that do not have taxable income consequences are more prevalent than } \\
\text { earnings management that have taxable income consequences. }\end{array}$ \\
\hline & $\begin{array}{l}\text { Das et al., } 2009 \\
\text { Intra-year earnings patterns should be viewed with suspicion in terms of earnings management } \\
\text { occurrence. }\end{array}$ \\
\hline & $\begin{array}{l}\text { Baker et al., } 2009 \\
\text { The viability of the grants strategy will vary with the level of incentives and opportunities. }\end{array}$ \\
\hline & $\begin{array}{l}\text { Davis et al., } 2009 \\
\text { Both short and long-term auditor tenure are associated with increased use of discretionary accruals to } \\
\text { meet or beat earnings forecasts in the pre-SOX period, but the results disappear following SOX. }\end{array}$ \\
\hline \multirow[t]{11}{*}{2010} & $\begin{array}{l}\text { Jackson and Liu, } 2010 \\
\text { Conservatism may facilitate earnings management. Firms manage bad debt expense downward (and } \\
\text { even record income-increasing bad debt expense) to meet or beat analysts' earnings forecasts and that } \\
\text { conservatism accentuates the extent to which firms manage bad debt expense. }\end{array}$ \\
\hline & $\begin{array}{l}\text { Armstrong et al., } 2010 \\
\text { Financial transparency reduces agency conflicts and has the potential to limit earnings management } \\
\text { activities. }\end{array}$ \\
\hline & $\begin{array}{l}\text { Barth and Taylor, } 2010 \\
\text { Earnings management can have different sources and only few can be associated with estimating fair } \\
\text { value. Not all estimations for fair value can lead to earnings management. }\end{array}$ \\
\hline & $\begin{array}{l}\text { Gunny, } 2010 \\
\text { Earnings management via real earnings management is not opportunistic, but consistent with managers } \\
\text { attaining benefits that allow better future performance or signaling. }\end{array}$ \\
\hline & $\begin{array}{l}\text { Seybert, } 2010 \\
\text { When R\&D expense is capitalized earnings management can increase. Mandatory capitalization of R\&D } \\
\text { do not reduce real earnings management. }\end{array}$ \\
\hline & $\begin{array}{l}\text { Baber et al., } 2010 \\
\text { Reversals of earnings management constrain the ability to manage earnings. }\end{array}$ \\
\hline & $\begin{array}{l}\text { Bagnoli and Watts, } 2010 \\
\text { Product market competition can be affected by earnings management and vice versa. }\end{array}$ \\
\hline & $\begin{array}{l}\text { Barua et al., } 2010 \\
\text { Managers use classification shifting to manage earnings for reporting discontinued operations. }\end{array}$ \\
\hline & $\begin{array}{l}\text { Stubben, } 2010 \\
\text { Revenues models for detecting earnings management are less biased than accrual models. }\end{array}$ \\
\hline & $\begin{array}{l}\text { Dechow et al., } 2010 \\
\text { A better "monitoring', do not necessarily reduces earnings management or CEO pay-sensitivity to } \\
\text { reported securitization gains. }\end{array}$ \\
\hline & $\begin{array}{l}\text { Cohen and Zarowin, } 2010 \\
\text { SEO firms engage in real activities manipulation, and the decline in post- SEO performance due to the } \\
\text { real activities management is more severe than that due to accrual management. }\end{array}$ \\
\hline 2011 & Choudhary, 2011 \\
\hline
\end{tabular}




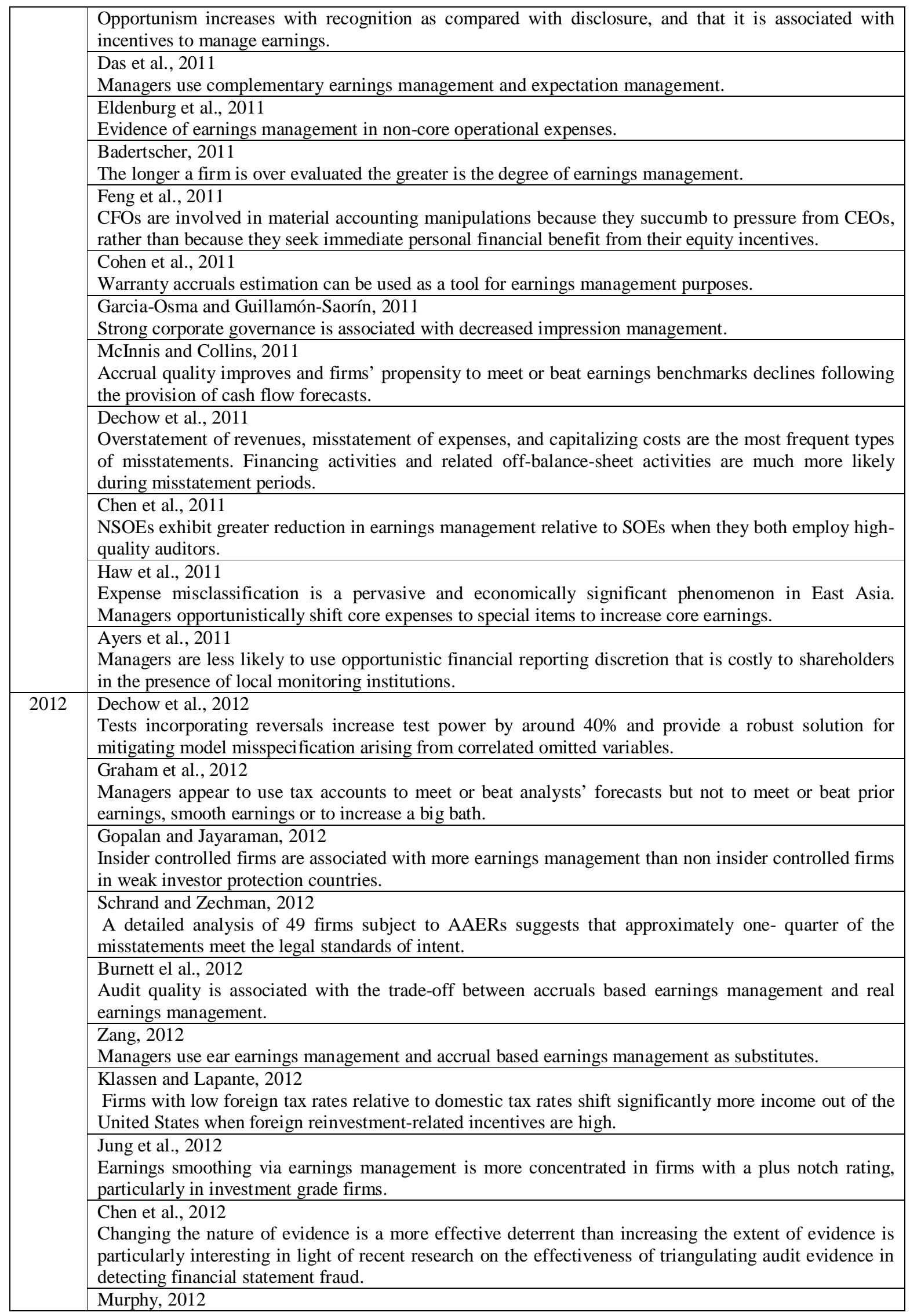




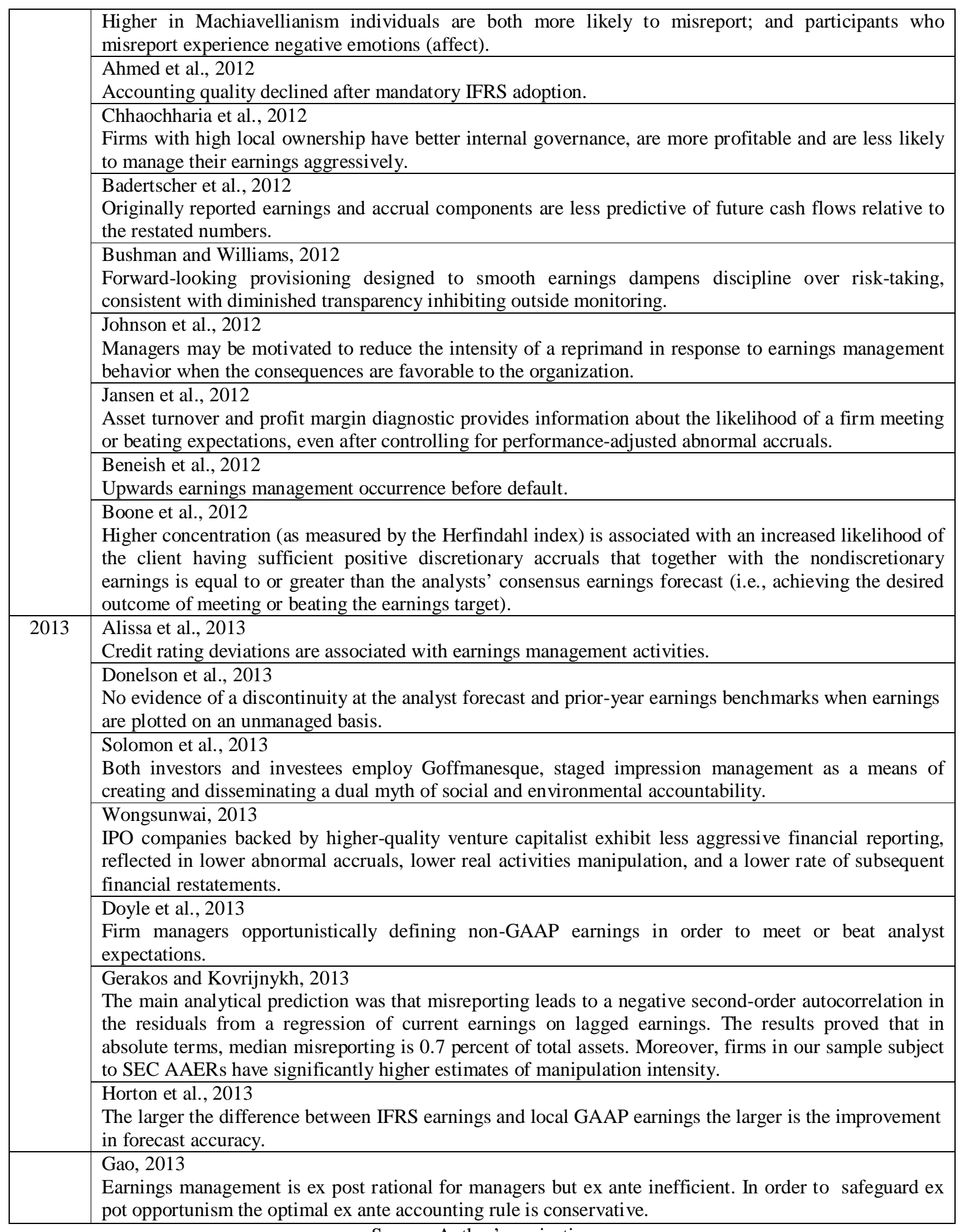

Source: Author's projection 